\title{
Juking the Stats? Authoritarian Information Problems in China
}

\author{
JEREMY L. WALLACE*
}

Economic statistics inform citizens of general conditions, while central leaders use them to evaluate local officials. Are economic data systematically manipulated? After establishing discrepancies in economic data series cross-nationally, this article examines Chinese sub-national growth data. It leverages variation in the likelihood of manipulation over two dimensions, arguing that politically sensitive data are more likely to be manipulated at politically sensitive times. Gross domestic product (GDP) releases generate headlines, while highly correlated electricity production and consumption data are relatively unnoticed. In Chinese provinces, the difference between GDP and electricity growth increases in years with leadership turnover, which is consistent with juking the stats for political reasons. The analysis points to the political role of information and the limits of nonelectoral accountability mechanisms in authoritarian regimes.

Making robberies into larcenies. Making rapes disappear. You juke the stats, and majors become colonels. I've been here before.

The Wire, 2006

GDP figures are 'man-made' and therefore unreliable, [then-executive vice premier] Li [Keqiang] said. When evaluating Liaoning's economy, he focuses on three figures:

1) electricity consumption, which was up 10 per cent in Liaoning last year;

2) volume of rail cargo, which is fairly accurate because fees are charged for each unit of weight; and

3) amount of loans disbursed, which also tends to be accurate given the interest fees charged.

By looking at these three figures, Li said he can measure with relative accuracy the speed of economic growth. All other figures, especially GDP statistics, are 'for reference only,' he said smiling.

Wikileaks, Cable 07BEIJING1760, 15 March 2007

Economic statistics dominate policy analyses, political discussions, and the study of political economy. Yet while many are quick to question the veracity of politicians' statements, officially released economic statistics are rarely treated with similar skepticism. For instance, it is widely believed in the Western media that the Chinese

* Department of Political Science, Ohio State University (email: wallace.521@osu.edu). The author wishes to thank Marcus Kurtz, Sarah Brooks, Irfan Nooruddin, Ohio State's Political Economy Working Group, Eva Bellin and Jessica Weiss, as well as Pu Xiaoyu and Jennifer Mayer for research assistance. Online appendices and replication files are available at http://dx.doi.org/doi: 10.1017/ S0007123414000106. 
Communist Party (CCP) adjusts economic data to paint a positive portrait of the country's economic situation for political purposes, to protect its image of delivering rapid economic growth. Under what conditions do governments manipulate economic statistics?

Democratic leaders tend to lose elections when macroeconomic trends are unfavorable. ${ }^{1}$ Similarly, poor economic performance is one of the principal threats facing an authoritarian regime. ${ }^{2}$ During times of poor economic performance, grievances accumulate among the population as individuals are laid off, opportunities disappear, and incomes fall. Yet, in contrast to democracies where elections serve as information gathering mechanisms, an individual living under dictatorship understands her own inability to oust a regime singly and even to make assessments about the willingness of others to rebel, especially while the greengrocer keeps a propaganda poster in the window. ${ }^{3}$ National income statistics, such as GDP, indicate the country's overall economic trajectory and can aid those seeking to undermine regimes. Releasing economic statistics 'helps to coordinate expectations that economic hardships are widely shared, facilitating mobilization against under-performing autocrats'. ${ }^{4}$ Hollyer et al. (2011) models the choice facing regimes regarding whether or not to release economic statistics, given the potential costs of doing so. If information aids collective awareness of economic difficulties, then failing to release (or collect) these statistics might reduce the probability of collective action. Yet not releasing such information may itself signal weakness, as can the strategic timing of elections. ${ }^{5}$

Previous research has implicitly assumed that leaders can only choose whether or not to release economic data. This overlooks the possibility that leaders might choose to release manipulated data that presents the economic environment in a more favorable light than is really the case. ${ }^{6}$ In this article, I focus on the possibility that leaders might 'juke the stats' (that is, manipulate the data). Such manipulated statistics, especially in environments where manipulation is hard to detect, can avoid the negative signals associated with nonrelease while maintaining or expanding the dampening effect on individuals' assessments of collective discontent.

Dictatorships are not beholden to the same kind of regularized mass referenda on their rule as democratic regimes. At the national level, dictators, operating with few (if any) checks on their authority, might be willing and able to manipulate economic data. At a moment of crisis, such 'juking the stats' might obfuscate the situation's desperation from the people and reduce the risk of collective action against the regime. ${ }^{7}$

Data may be manipulated to shift society's views of a regime, but manipulated data may also emerge from intra-regime dynamics. Since citizens value economic development, hierarchical regimes interested in monitoring lower-level officials without undue auditing expenses can use economic statistics as information shortcuts. Lower-level officials, knowing

${ }^{1}$ Drazen 2001.

${ }^{2}$ Geddes 1999; Huntington 1968. In this article, I use dictatorial, nondemocratic and authoritarian regime interchangeably, following the Democracy and Dictatorship (DD) dataset's coding, as detailed below.

${ }^{3}$ Fearon 2011; Kuran 1991a, 1991b.

${ }^{4}$ Hollyer, Rosendorff, and Vreeland 2011.

${ }^{5}$ Smith 2004. Thanks to an anonymous reviewer for suggesting this connection.

${ }^{6}$ While certainly possible in democratic contexts, I argue below that manipulation of economic statistics is less likely to occur in the free media environments that predominate in democracies. Regimes might also manipulate data in the opposite direction - that is, under-reporting wealth or growth - to obtain access to concessional loans (Kerner, Jerven, and Beatty 2013).

${ }^{7}$ Acemoglu and Robinson 2005. 
the statistics by which they are judged and having some control over the bureaucrats who create those statistics, have an incentive to juke the stats. A central authority that judges sub-national officials using performance-based targets is often reliant on these same officials to supply them with the relevant data. This principal-agent problem bedevils a dictator who is interested in creating an accountability mechanism for subordinates based on economic data. Sub-national leaders may be rewarded on the basis of manipulated data, since monitoring costs make it expensive (and nigh impossible) for central authorities to know the real situation on the ground with certainty.

Questioning the veracity of economic statistics quickly leaves investors, analysts, forecasters, and social scientists without sure footing. Once one entertains the possibility that economic data are manipulated, how can one demonstrate this to be the case or not? The difficulty becomes finding data that should be relatively free from such influence that can be used to evaluate the extent of manipulation.

This article leverages variation in the likelihood of data manipulation over two dimensions in China. First, some types of data are more politically sensitive and hence more likely to be manipulated than others. Secondly, some times are more politically sensitive than others, so data reported at these times should show more evidence of tampering than during other (less sensitive) periods. I argue that GDP growth, which is both an abstract concept and the star measure among national statistics, is more likely to be manipulated than its close correlates, growth in electricity production and consumption.

I test for manipulation using a two-stage approach. First, when electricity and GDP growth diverge, after controlling for real sources of such divergence, manipulation of the GDP series is a possible culprit. ${ }^{8}$ Secondly, incentives to manipulate are likely to vary over the course of political cycles. For example, with promotions on the line, sub-national leaders might overestimate GDP growth during political turnovers as a signal of competence and success. ${ }^{9}$ Or a newly installed leader might immediately inflate growth figures as a signal of competence upon arrival. ${ }^{10}$ Such data manipulations are artifacts of leaders' political incentives, and exist in the statistics rather than the real economy - that is, they represent a reported political business cycle. ${ }^{11}$ As home to the world's second-largest and fastest-growing economy, China's economic statistics move markets globally. Yet despite doubts about their trustworthiness, systematic evidence questioning the validity of the numbers is rare.

First, I develop a theoretical argument regarding why we might expect data manipulation to be more common in dictatorships. Then, I discuss recent examples of patterns that suggest such manipulation occurs in China and present cross-national evidence indicative of dictatorships deliberately overstating their GDP statistics. Next, I show that leadership turnover cycles influence reported levels of economic growth at the sub-national level in China. The annual and quarterly data demonstrate that the difference between economic and electricity growth is larger in the years of a political turnover in a province, which is

\footnotetext{
8 Economists looking for the size of the 'unofficial' economy in different countries have similarly compared electricity and GDP series. Taking the electricity consumption value as given, the difference in the official level and the GDP level estimated from electricity consumption is declared the size of the unofficial economy (Johnson, Kaufmann, and Shleifer 1997).

9 To clarify, I use the acronym GDP for the estimate of the local economy's size rather than Gross Regional Product for subnational units, following Chinese usage.

${ }^{10}$ Or a new leader could initially tamp down growth numbers to show improvement over time during her tenure in a locality.

11 Contrasted with a real political business cycle in which the economy itself (and not the statistics purporting to measure the economy) is manipulated (e.g., Nordhaus 1975); see discussion below.
} 
consistent with the hypothesis that political cycles lead to upward-biased reporting at key moments. ${ }^{12}$ I conclude with a discussion of the dilemmas that dictatorships face in holding sub-national officials accountable for their performance in the absence of elections and caution social scientists in our use of officially reported, politically sensitive economic statistics from dictatorships. ${ }^{13}$

\section{ARGUMENT}

Rulers are often removed from office during recessions or periods of negative trends in macro-economic indicators. ${ }^{14}$ Rulers, regardless of regime type, are beholden to the public (or subsets of them - that is, selectorates) and attempt to appease them in order to remain in power. ${ }^{15}$ Poor economic growth harms regime survival in non-democracies even after controlling for numerous institutional and structural factors. ${ }^{16}$

Obviously, an official from the statistical office does not call the president and ask for her resignation upon finding that the estimated GDP growth figure is negative for a third consecutive quarter. The mechanisms connecting poor economic performance and regime turnover are informational and aspirational. In particular, the public release of negative economic information increases the probability that others will be predisposed to join collective action against a regime. ${ }^{17}$ Public and official acknowledgement of poor economic performance lets individuals know that they are unlikely to be alone in holding grievances against the regime, and that they are not alone in their experience of hard times. Believing that others also hold the regime in contempt might lead a political entrepreneur to act against the regime in ways that could bring about its end. Importantly, political entrepreneurs - either regime elites or outsiders - could take the measure of the regime in such a weakened moment and move to seize power, knowing that popular sentiment is less likely to be against them than if times were better generally.

If a regime can successfully juke the stats, it can muddy these waters. Some may stop seeing themselves as among a large cohort that is negatively disposed toward the regime. Individuals may well think that they are, if not precisely alone in their bad circumstances, then perhaps part of a smaller segment of the population that has drawn the short end of the stick in times of general plenty. Individuals who do not believe that the citizenry is aggrieved enough to participate in (or at least tacitly support) revolutionary action are less likely to move forward with such seditious acts.

In addition to manipulated statistics arising from a desire to misinform the population (including the elite), intra-regime political dynamics can cause the stats to be juked. Regimes tend to value strong economic statistics, as they publicly signal the regime's successes with the ensuing salutary political benefits. For busy central elites, evaluating the situations in, and leaders of, different localities can be taxing. Such elites may use GDP or other metrics to evaluate leaders of these sub-national units. However, the local

${ }^{12}$ The dependent variable is GDP growth minus electricity growth, and can be negative if electricity growth is larger than GDP growth.

13 Analyses that rely solely on dictatorships for politically sensitive data that are easily doctored should be taken with a grain of salt.

${ }^{14}$ Chiozza and Goemans 2004.

15 Ames 1970; Bueno de Mesquita et al. 2003; Geddes and Zaller 1989; Magaloni 2006; Nordhaus 1975; Pepinsky 2007.

${ }^{16}$ Gandhi 2008; Geddes 1999.

${ }^{17}$ Hollyer, Rosendorff, and Vreeland 2011. 
officials being judged by GDP maintain some power over the bureaucrats who create the local GDP estimates. While national-level officials are far away, local officials may take advantage of their position to adjust the numbers in their favor.

The threat of poor economic performance, and the public acknowledgement of such via the release of official statistics, manifests itself differently across regime types. In a democratic context, the potential for losses in the next election looms. Political science and economics have developed a large literature on the political business cycle, which tracks how (primarily democratic) regimes adjust both economic performance and election timing to avoid pitfalls related to economic recessions. ${ }^{18}$ Elections are focal points, and the political principals in democracies - voters - reward strong performance in the lead-up to these events. Voters, either out of myopia or interpreting improved economic trends and stimulus as a rational signal of leader competence, reward such behavior in elections. ${ }^{19}$

Some electoral dictatorships also exhibit behavior that is in line with the expectations of the political business cycle literature based on democracies. ${ }^{20}$ For dictators, in the absence of real national elections, economic focal points arise during economic downturns and food price spikes; for sub-national leaders, focal points relate to selection and promotion cycles. Even in regimes such as China's, which does not have popular elections for the national leadership, there are indications that political business cycles line up with national and sub-national political turnover. ${ }^{21}$

I argue that in dictatorships, sub-national- and national-level leaders have the option to do what the democrat would do - improve the economy - but also might pursue political success in a way that is unlikely to be successful in a democratic system - by improving the numbers that describe the economy. To the extent that reported numbers provide cues or 'information shortcuts' to evaluating performance, ${ }^{22}$ manipulating economic statistics may represent one strategy for improving either confidence in the regime or the career prospects of sub-national leaders.

Such motives may exist in democracies as well. As long as citizens are only imperfectly aware of the macro-economic situation, update their beliefs about the economy based on official releases, and vote in part according to these beliefs, then leaders will have a motive to adjust those numbers in a positive direction. However, democracies comparatively constrain leaders' ability to misrepresent politically salient data. In democracies, the individuals whose activities make up the economy - and so are aware of current conditions - are also the principals. ${ }^{23}$ The people reward and punish government officials through elections; they know the state of the economy, and thus hold their elected officials accountable for performance. $^{24}$

The principal constraint on the manipulation of economic data is the expected cost of such fraud being exposed. This expected cost has two components: the cost and likelihood of exposure. While at any given moment there might be a political or economic upside to

${ }^{18}$ Kayser 2005; Nordhaus 1975.

19 Drazen 2001.

${ }^{20}$ Blaydes 2010; Magaloni 2006; Pepinsky 2007.

${ }^{21}$ Guo 2009; Tao 2006.

${ }^{22}$ Lupia and McCubbins 1998.

${ }^{23}$ Ober (2008) argues that the success of democratic Greek city-states compared with less-democratic rivals was due to the informational advantages of the former.

${ }^{24}$ This is the case in aggregate, even if each individual only knows her own situation (Fearon 2011). 
juking the stats to send a positive signal, if exposed, this fraud would destroy the regime's credibility and carry with it substantial downside risks. For a regime, investment levels would fall due to heightened uncertainty, and future statistics would be dismissed as cheap talk. For a sub-national official, likely consequences include official reprimands, reduced promotion trajectory, termination of employment or arrest.

The likelihood of exposure and punishment varies across regime type, however, due to elections and differences in levels of press freedom. Dictatorships without a free press and elections have a greater ability to dominate beliefs about the state of the economy than do their democratic counterparts. Polity score (a measure of democracy) and lack of press freedom, collected by Freedom House, are negatively correlated $(r=-0.8)$, showing a strong connection between these two variables. In fact, some go so far as to include freedom of the press in their definition of democracy. ${ }^{25}$ As such, outside investigations may assess the accuracy of official numbers less often in dictatorships. The Chinese regime, for example, restricts surveys on politically sensitive topics, leading it to be dropped from Transparency International's Global Corruption Barometer 2013. ${ }^{26}$ With the chances of exposure and the expected cost of juking the stats both lower in dictatorships, we might expect such actions to be more common in non-democracies. Systematic discrepancies in reported economic figures across regime types that cannot be accounted for by real economic or political differences would thus suggest data manipulation in dictatorships.

The existence of bureaucracies devoted to the collection and dissemination of such statistics suggests that not all official data from nondemocratic regimes are manipulated. The production of numerous statistical yearbooks along with monthly and quarterly updates of economic and social conditions published online would constitute an impressive act of political theater if it were all fictional. The Chinese statistical xitong system has an estimated 80,000 employees with an additional support staff of equal size. ${ }^{27}$ In the summer of 2009, China's National Bureau of Statistics (NBS), released a series of songs intended to improve bureau morale and demonstrate the importance of their work. ${ }^{28}$ Yet these bureaucrats report to politicians focused on preserving the CCP's hold on power.

Nonetheless, while dictators may benefit from having this data manipulation arrow in their quiver, I argue that this weapon can also be wielded against them. Regimes wanting to engender strong economic performance can put into place political incentives that tie sub-national officials' careers to their economic track record. This accountability mechanism, though, is subject to the same kind of gaming-the-system tactics that national-level leaders might use. Local agents with similar incentives may abuse their information advantages by manipulating the data they report to the center. Even if central officials are aware of the possibility of data manipulation, the costs of auditing may be high enough for it to be a possibly successful tactic.

In sum, following a basic cost-benefit analysis, when its benefits exceed its expected costs, I expect to find data manipulation. The Juking the Stats Hypothesis is that data

${ }^{25}$ Schmitter and Karl 1991.

26 Areddy 2013.

27 Holz 2005.

28 The program was part of the sixtieth anniversary of the establishment of the People's Republic of China (PRC) celebrations for the NBS (e.g., 'I am Proud to Be a Brick in the Statistics Building of the PRC' and 'Love the Homeland, Love Statistics') (Canaves 2009). 
manipulation is most likely in nondemocratic regimes during politically sensitive moments and for politically sensitive indicators.

\section{AUTHORITARIAN INFORMATION PROBLEMS}

What evidence should call the official economic statistics of dictatorships into doubt? Juking the stats can take many forms. While this article focuses on the alteration of politically sensitive numbers, other tactics include substituting a different measure or data series, or shifting the technical details of measurement. In China at the beginning of the decade, the discrepancies between official air pollution statistics and readings from nongovernmental sources were comical. The US Embassy's Beijing Air monitor exceeded its maximum possible reading in 19 November 2010 and reported the air quality in Beijing that day as 'crazy bad', resulting in a minor diplomatic incident. In October 2011, the US Embassy's measure was 'beyond index' while Beijing's official estimate was 'slightly polluted'. ${ }^{29}$ Yet whether the Chinese data have been altered to politically convenient levels remains unclear. ${ }^{30}$ What is clear, however, is that the official Beijing air quality metric reported levels of particulates of a different size than the US Embassy, and the Chinese government monitoring locations were shifted to more suburban areas with cleaner air. ${ }^{31}$ Such tactics are more transparent to outside observers, as discrepancies in the data are readily accounted for on technical grounds. GDP, on the other hand, is a more abstract construct that lacks many readily observable alternatives. Electricity, given its ubiquity in the modern economy, provides one possible alternative measure of an economy's size and trajectory.

National-level Chinese electricity and GDP statistics diverged conspicuously in the wake of the collapse of US investment bank Lehman Brothers in September 2008. Many believed that the Chinese government was propping up its GDP growth rate estimates to ease concerns that its economy was grinding to a halt as demand for exports dropped with the global financial crisis. ${ }^{32}$ The divergence between the GDP growth figure and electricity production growth suggests that the regime manipulated the closely watched headline figure to boost confidence, while faithfully reporting the less-examined electricity series.

This divergence is captured in Figure 1, which plots two national growth rate series for the past decade: monthly electricity production and quarterly GDP. ${ }^{33}$ There is a strong correlation between the two data series. ${ }^{34}$ The GDP series has a lower mean than the electricity production growth series, and exhibits much less volatility. In the summer of 2008, reported levels of electricity production dropped precipitously, sinking deeply

29 Demick 2011.

${ }^{30}$ If the data were in fact manipulated, whether it was done to change social or central perspectives also remains murky.

31 See Andrews (2011) for more details. By 2013, Chinese official air pollution data have improved both in quality and transparency.

32 E.g., Smith 2009.

33 The values of the monthly electricity series are plotted, but the line represents the three-month moving average of that data. The data source is www.stats.gov.cn. For more details, see the Appendix.

34 The electricity series jumps relative to the GDP data during the summer of 2002 due to an adjustment that corrects for previous under-reporting of coal usage around the turn of the century because of a policy of shuttering small coal mines due to safety concerns (Rawski 2001; Sinton 2001). This episode supports the general argument - that dictatorships face data manipulation problems - while showing that non-GDP data can also be subject to these pressures. See Naughton (2007) for details. 


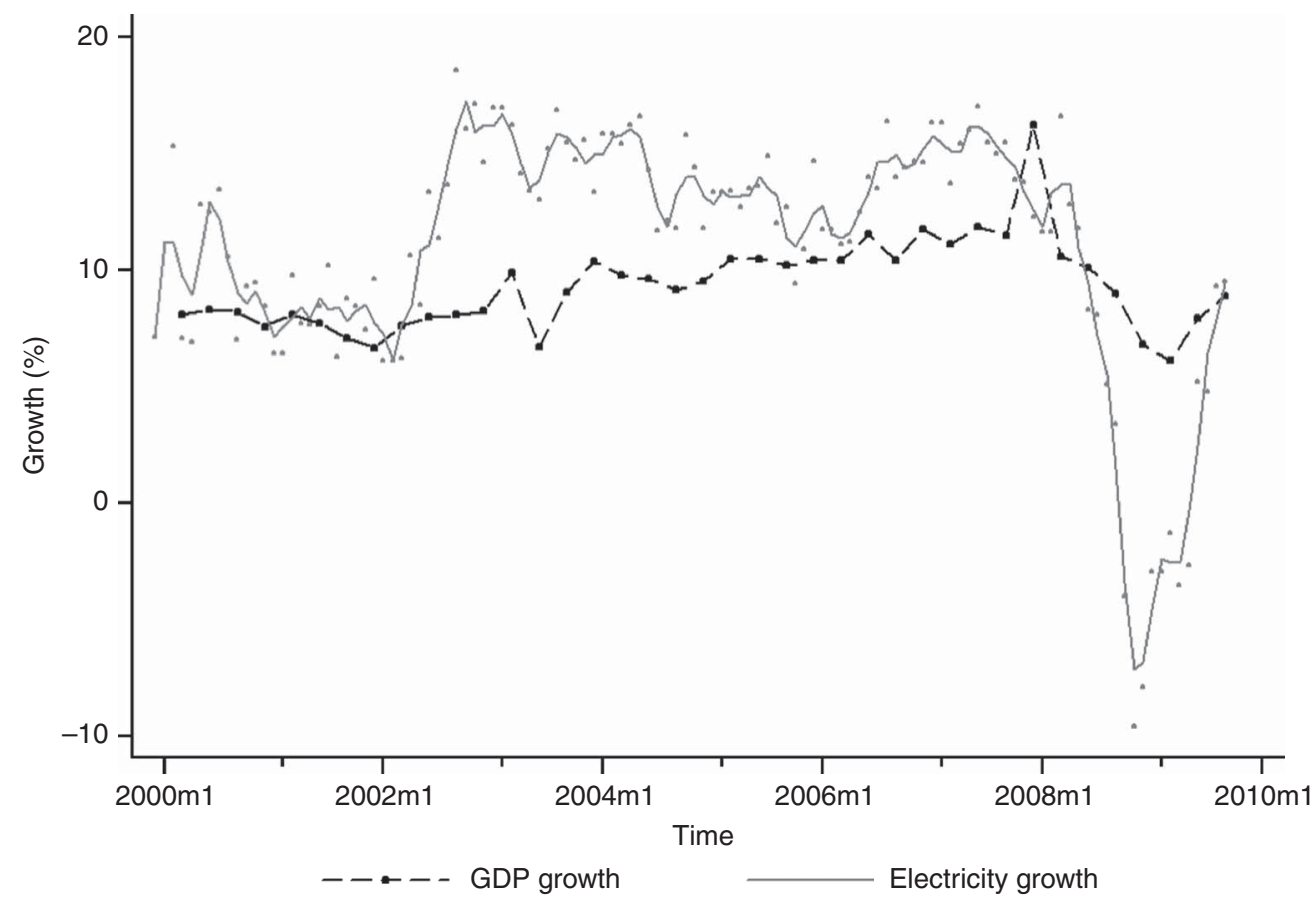

Fig. 1. Divergence between Chinese electricity production and GDP in monthly data

Note: an adjustment was made to the monthly electricity data series in order to address the high level of volatility associated with Chinese New Year. In particular, the monthly growth figures from January and February were averaged. There is no substantial change in the shape of the post-Summer 2008 divergence that is the focus of the figure here. Both data series show year-on-year growth figures. The electricity production data plot individual month data points, while the solid gray line follows the three-month moving average. The GDP growth data are quarterly; the black dashed line simply connects the actual data points. Data from the Chinese National Bureau of Statistics.

into negative territory, with 10 per cent year-on-year declines at the beginning of 2009 . By contrast, GDP growth takes a much more minor dip, only falling to 6.8 per cent in the fourth quarter of 2008 - a still quite rapid growth rate - before recovering in 2009 .

The same discrepancy appears when other economic data series, such as rail traffic or exports, are compared to GDP. ${ }^{35}$ More broadly, this divergence appears precisely at the moment when it was most politically expedient for the regime to report continued economic growth. The combination of political convenience and disparity with more obscure series gives the appearance of manipulation.

Suggestive evidence indicates that such discrepancies are far from unique to China. Examining patterns in GDP and electricity cross-nationally shows divergence across regime types. While under democratic regimes GDP per capita figures correlate with electricity consumption at the extremely high level of 0.85 , in dictatorships, the relationship is substantially weaker at only $0.71 .^{36}$ The ratio of reported GDP to electricity consumption is

\footnotetext{
${ }^{35}$ See Appendix for additional figures depicting a series showing continuity with the electricity series and divergence from GDP.

36 The data for GDP per capita and electricity consumption per capita come from the World Development Indicators and cover the years 1960-2008. I use a dichotomous conception of regime type
} 
also substantially greater in dictatorships than democracies. ${ }^{37}$ Finally, for a given change in electricity consumption per capita, dictatorships report substantially greater gains than democracies in GDP per capita. ${ }^{38}$

Data manipulation is not wholly unexplored territory in political science. ${ }^{39}$ Scholars have suggested that bureaucrats manipulate data to create opportunities for corruption. For example, managers and bureaucrats in the Soviet industrial system consistently underestimated public demand for their products to generate scarcity, so that officials could request bribes for privileged access to these goods. ${ }^{40}$ The disastrous famine of the Chinese Great Leap Forward under Mao is another calamitous example. Lower-level officials over-reported grain production to earn plaudits from the center. ${ }^{41}$ The central government, believing these production numbers, took its normal percentage of the harvest for distribution to urban areas. Thus rather than cutting the hair of the farmers, the taxes scalped them. The over-reporting and resulting over-extraction left the farmers with nothing to eat; this, along with the other policies of the Great Leap Forward, caused a famine that killed approximately thirty million Chinese. ${ }^{42}$ In the contemporary period, at the village level in China, falsification of income statistics has been shown in recent survey data. ${ }^{43}$ Yet little is known about the extent of such activities at higher levels.

Chinese local officials compete against each other for promotions. ${ }^{44}$ Official Chinese documents state that GDP and other economic measures of growth matter in promotion decisions, ${ }^{45}$ although at the highest levels other factors such as political connections, education and revenue collection may weigh even more heavily. ${ }^{46}$ Yet the data used to evaluate performance are collected and reported by the very officials being judged. Subnational incentives could affect GDP data reporting by creating constant upward bias.

\footnotetext{
(F'note continued)

from Joseph Wright via the Quality of Governance dataset, in which all years that are coded as one of the various types of dictatorship by Wright form the set of non-democratic country-years; other cases are coded as 0 (Teorell et al. 2011; Wright 2008). If one prefers, the zeroes could be described as non-nondemocracies. That is, we are differentiating the clear non-democracies from other kinds of regimes. The DD data, another commonly used dichotomous measure of dictatorship, codes country-years as dictatorial by making democracy the 'restricted' category (Cheibub, Gandhi, and Vreeland 2010). Results are robust to the use of this alternative measure of regime type, as shown in the Appendix.

37 For dictatorships, the mean was $\$ 4$ for every kilowatt-hour of electricity consumption compared with less than $\$ 2.89$ for democracies, p-value $<0.0001$.

${ }^{38}$ This result is robust to the use of levels rather than changes, different measures of regime type and using the natural log of the variables in question to deflate the influence of right-skewed outliers. In a regression with the dependent variable of changes in GDP per capita accounted for by changes in electricity consumption per capita, a dummy variable for dictatorship has an estimated coefficient of \$27.

39 Rigged elections could also be thought of as cases of data manipulation (Bueno de Mesquita et al. 2003; Magaloni 2006; Simpser 2013).

40 Shleifer and Vishny 1999.

41 Bachman 1991; Kung and Chen 2011.

42 Lin and Yang 2000.

43 Tsai 2008.

44 Landry 2008.

45 Guo 2007; Landry 2008; Whiting 2000.

46 Lü and Landry (forthcoming); Shih, Adolph and Liu 2012. If GDP metrics are only of secondary concern for promotions but still exhibit patterns aligning political cycles rather than economic activity, then officials may be juking the stats to make sure they are doing everything possible to maximize their chances of advancement. Despite many weaknesses (Gleditsch 2002; Heston 1994), GDP continues to be the de facto measure of development and successful economic stewardship.
} 
Indeed, simply summing all of the provincial GDP totals for a given year produces a national GDP estimate that is consistently above the official national GDP figure; provincial growth rates all tend to be above the official national growth rate as well. ${ }^{47}$ The pressure to perform economically should affect all provinces at all times, and so does not necessarily represent a method of isolating political machinations in the data. Yet incentives to manipulate might manifest themselves in reported statistics only (or most strongly) during specific times. A natural starting point would be that political cycles may affect sub-national officials' incentives to manipulate the numbers on which their performance is being judged.

\section{RESEARCH DESIGN}

To conclude that a GDP growth series was fraudulent on the basis of one momentary deviation from expectations - even if that deviation were politically significant and convenient, such as the divergence in Chinese economic and electricity growth during the Great Recession depicted in Figure 1 - would be hasty. Repetitions of this pattern, however, are less easily accounted for by innocent explanations. To expand the number of observations under investigation, I analyze Chinese provincial-level data.

I examine the differences between provincial economic growth rates (measured as GDP growth) and electricity growth rates over time, as well as variation in political sensitivity using observed local leader turnover. The Juking the Stats Hypothesis holds that in years with local leader turnover, the result of subtracting the electricity growth rate from the GDP growth rate should increase. These moments are highly politically sensitive, and thus should reflect particular pressure to report inflated GDP data. ${ }^{48}$ While officials might have an incentive to overstate economic growth in all periods, the pressure to demonstrate stellar performance should be particularly strong surrounding moments of political turnover: outgoing leaders may hope to manipulate statistics in order to better their promotion prospects, and new leaders might want to increase growth to demonstrate their positive effect on performance.

The nature of political turnover within the CCP's elite levels is relatively opaque to outsiders, but its features allow us to isolate the possibility of political effects on the data. Officials are appointed to five-year terms at the county level and higher, but rarely serve them out in full before being promoted, demoted, moved laterally or removed. ${ }^{49}$ Countylevel leaders have average tenures of around three years, ${ }^{50}$ and provincial-level leaders are also often moved before the end of their official term. ${ }^{51}$ This has both advantages and disadvantages for the researcher. The opacity of the system precludes measures of

${ }^{47}$ However, the 2004 Chinese Economic Census showed that provincial officials were, on average, reporting growth rates that (at least in the lead-up to the census) were in line with the development of their economies, although there is debate over the extent to which the provinces were lucky that their biases aligned with the difficult-to-capture statistically and rapidly growing service (tertiary) sector. For more details on this episode see Holz (2008) or Naughton (2007).

48 Because of the opacity of turnover, it is impossible to discriminate perfectly whether the relevant economic data is generated under the outgoing or incoming leadership. The article finds empirical evidence of patterns that are consistent with local economic statistics in China being manipulated. These patterns align with the political cycle and are not explained by changes in the real economy.

49 Guo 2007. 2010 reforms extended such terms down to the township level as well.

50 Guo 2007; Landry 2008.

51 Li 2010. 
political turnover other than actual changes in leadership. The announcement of $X$ official being appointed governor of $Y$ province is unlikely to be news to insiders. Outsiders, though, are unaware of whether or when leaders are first told they are being judged or moved. Observed turnovers, then, are the best metric available to researchers. Additionally, the timing of the appointments is not uniform over time or space. Tenure durations vary by location, and officials are appointed and move on almost every year. Li presents a table of the set of provincial-level leaders as of June 2010 and finds that of the sixty-two positions, forty-eight came into office from 2007 to 2010; 2007 was the modal year with twenty-two appointments. ${ }^{52}$ The irregularity of personnel shifts has the advantage of separating turnover effects from year effects. ${ }^{53}$

\section{CHINESE PROVINCIAL ANALYSIS}

The analysis compares provincial-level economic and electricity growth series using both annual and quarterly data. China has thirty-one provincial-level units, which increases the number of observations under study compared to previous national-level analyses of data manipulation in China. ${ }^{54}$ The dependent variable is created by subtracting electricity from GDP growth. At the national level this difference (as depicted in Figure 1) is relatively small, with the exception of its explosion during the global financial crisis. For each time period, the province's reported GDP growth rate is subtracted by (1) the electricity consumption growth rate for the annual data and (2) the electricity production growth rate for the quarterly data. ${ }^{55}$

It should be noted again that the goal is not to analyze a political business cycle, but rather to assess whether the evidence is consistent with the manipulation of reported levels of GDP growth - separately from any potential economic factors that coincide with political cycles. ${ }^{56}$ Some of the political business cycles observed and analyzed in the literature may be artifacts of the manipulations of the data series rather than manipulations of the economy. ${ }^{57}$

The data required to test the Juking the Stats Hypothesis come from a number of different sources and exist at different time scales. The units of analysis are the provinceyear from 2000-09 and the province-quarter from 2001-08.

The GDP of a province is a measure of economic activity in that region. Although GDP is not traded across borders, there is substantial interprovincial trade in electricity, which complicates the quarterly analysis. Urban, industrialized areas import power from coalrich rural areas that surround them or from across the country. China has been investing

52 Li 2010.

53 If all officials were replaced, say, at the end of 2007, then it would be difficult to disentangle changes in the real economy that occurred in 2007 from the political effects of the turnover on the economic statistics reported by the provinces.

54 Rawski 2001; Sinton 2001.

55 Both quarterly data series are transformed, as described in detail below and in the Appendix. Subannual data on electricity consumption at the provincial level is not available. For more details on the construction of the dependent variable, see the Appendix. The differences between GDP growth and electricity production growth for the provinces are depicted in Appendix Figure 4. Tibet is absent from the annual data but present in the quarterly analyses.

56 cf. Guo 2009.

57 This is less the case with political budget cycles, as documented in Guo (2009), since budgets are rarely examined closely for their content as a measure of overall economic trends when compared with national account estimates. 
heavily in its electrical grid, specifically to carry power across vast distances from coal and wind sources in the north and west to the seaboard in the east, where demand is clustered. $^{58}$ Electricity trade only matters in the quarterly analysis, where production rather than consumption data are used.

A potential problem with using production data can be seen by considering how provinces decide which power to use first. If electricity importers reduce the use of imported electricity before (or at a greater rate than) locally produced power, then the relationship between the electricity production growth series and GDP growth rates will be confounded. However, this potential problem does not affect the analysis for two reasons. First, electricity production decreased for electricity-importing provinces during the global economic crisis, which shows that the interprovincial Chinese electricity market is not characterized by undue local favoritism. Secondly, the quarterly models also include an annual estimate of each province's net electricity exports to capture differences between electricity importers and exporters.

The independent variable for both the annual and quarterly analyses is elite political Turnover, which is a dummy variable coded 1 in years in which there was a change at the top of the party or government leadership of the province. If there was a change in at least one of the two positions (party secretary or and governor) in a given year, that year (or the quarterly analysis of all the quarters within that year) was coded 1 as having a turnover; all other times were coded 0 . In the quarterly analysis, I also include a $\Delta$ Turnover measure, as the political dynamics at play might not only be present in the final year of a leader's tenure but also as a new leader enters office. ${ }^{59}$

Control variables for the analyses are factors in the real economy that might affect the $G D P$-Electricity growth rate differential: industrial value-added growth, provincial per capita GDP, the service sector's share of the provincial economy, and the net exports of electricity into (or out of) a province. Industrial Growth captures the performance of the real economy's most electricity-intensive sector. Faster industrial value-added growth should be associated with relatively greater increases in electricity consumption than GDP, and thus smaller (or more negative) values of the dependent variable. GDP Per Capita could have an effect in either direction. If considered a measure of state capacity, then richer provinces may be expected to have more professional statistical capabilities, and so the expected coefficient would have a negative sign. However, richer areas are also likely to have the most developed service economies, which points toward faster GDP than electricity consumption/production growth. The annual analysis includes an estimate of the share of GDP in the Service Sector, which attempts to measure this factor more directly. Finally, Net Electricity Exports are included in the quarterly analysis to ensure that the use of electricity production rather than consumption data is not driving the results.

The results support the Juking the Stats Hypothesis. Model 1.1 finds that there is a positive relationship between Turnover and the difference between reported GDP and electricity consumption growth. If we - following Li Keqiang - assume that it is the economic growth series that is being manipulated due to political forces, then an increase

\footnotetext{
58 See Appendix Figure 6 for a depiction. A map of the average import/export status of provinces from 2001-08 is provided in Appendix Figure 5.

$59 \Delta$ Turnover equals 1 if the prior year had zero turnovers while this year had one $(0,1) ; 0$ if there is no change in the number of turnovers from the previous year (either $(0,0)$ or $(1,1)$ ); and -1 if the prior year had a turnover while this year did not $(1,0)$.
} 
TA B L 1 Chinese Provinces' Annual Data Jukes with Political Cycles

\begin{tabular}{lcccc}
\hline \hline & Model 1.1 & Model 1.2 & Model 1.3 & Model 1.4 \\
\hline Turnover & $1.02^{*}$ & $0.95^{*}$ & $0.90^{*}$ & $1.02^{* *}$ \\
& $(0.52)$ & $(0.51)$ & $(0.50)$ & $(0.52)$ \\
Industrial Growth & & $-0.15^{* *}$ & $-0.23^{* * *}$ & $-0.18^{* * *}$ \\
& & $(0.07)$ & $(0.08)$ & $(0.07)$ \\
GDP Per Capita & & $11.15^{* * *}$ & $2.04^{* *}$ \\
(logged) & & $(3.01)$ & $(0.83)$ \\
Service Sector & & & -5.86 \\
(\% GDP) & & & $-74.94^{* *}$ & $(5.06)$ \\
Constant & -0.79 & $(7.56)$ & $(28.83)$ & $(10.26$ \\
& $(0.96)$ & YES & YES & YO \\
Province FE & YES & YES & YES & YES \\
Year FE & YES & 299 & 299 & 299 \\
Observations & 299 & 0.28 & 0.30 & 0.29 \\
R-squared & 0.27 & 30 & 30 & 30 \\
\# of Provinces & 30 & & & \\
\hline \hline
\end{tabular}

Note: dependent variable is Provincial GDP Growth-Electricity Consumption Growth, annual data from 2000-09. Robust standard errors in parentheses. ${ }^{* *} \mathrm{p}<0.01,{ }^{*} \mathrm{p}<0.05,{ }^{*} \mathrm{p}<0.1$. Only thirty provinces are included; Tibet is omitted due to missing electricity consumption data.

in the difference between these series represents an increase in the reported GDP growth rate. In the case of Model 1.1, in years with a turnover in a province, the reported GDP growth rate is higher on average by slightly over a full percentage point, holding the other factors constant. The estimated size of the coefficient is relatively stable at around 0.9-1.0 per cent in all of the models in the annual analysis, even controlling for industrial growth, GDP Per Capita and Service Share of the economy, as well as for year and province fixed effects.

The negative and statistically significant estimate of the industrial value-added coefficient in all of the models in Table 1 accords with the notion that as the industrial sector in a province grows, so too should its electric intensity. The sign of the coefficient for the GDP Per Capita variable, however, did not have a clear prediction. The results indicate that richer provinces report higher GDP growth rates, given the growth in their electricity consumption, than poorer provinces. This result is not definitive evidence of a predisposition to manipulate data in richer areas, since differences in the nature of the economies of rich and poor provinces might account for this discrepancy. Yet the most logical candidate for such a structural difference, service sector size, is statistically insignificant. If anything, provinces that have relatively large shares of their economy based on the service sector are associated with smaller, not larger, growth rate differentials. ${ }^{60}$ The annual analysis, in sum, demonstrates that GDP growth estimates are systematically higher in key moments of the political cycle.

The quarterly results seen in Table 2 exhibit almost precisely the same patterns as those described in the annual analysis. Political turnover is again associated with a positive bump in the GDP-Electricity growth rate, ranging from slightly more than 1 per cent to over 1.5 per cent. Even in the context of the rapid growth of the Chinese economy, a

${ }^{60}$ The coefficient of the Service Sector variable is negative when GDP per capita is dropped from the model, but this only holds when the model includes fixed effects. As there is relatively little change in these metrics over time, the substantive significance is unclear. 
TABLE 2 China's Provinces Report Faster Quarterly GDP Growth during Turnovers

\begin{tabular}{|c|c|c|c|c|c|}
\hline & Model 2.1 & Model 2.2 & Model 2.3 & Model 2.4 & Model 2.5 \\
\hline Turnover & $\begin{array}{l}1.55^{* *} \\
(0.64)\end{array}$ & $\begin{array}{l}1.18^{*} \\
(0.62)\end{array}$ & $\begin{array}{l}1.53^{* *} \\
(0.65)\end{array}$ & & \\
\hline$\Delta$ Turnover & & & & $\begin{array}{l}1.03 * * \\
(0.46)\end{array}$ & $\begin{array}{l}1.19^{* * *} \\
(0.44)\end{array}$ \\
\hline Industrial Growth & $\begin{array}{l}-0.25^{* * *} \\
(0.09)\end{array}$ & $\begin{array}{l}-0.23 * * * \\
(0.08)\end{array}$ & $\begin{array}{l}-0.24 * * * \\
(0.07)\end{array}$ & $\begin{array}{l}-0.23^{* * *} \\
(0.08)\end{array}$ & $\begin{array}{l}-0.24 * * * \\
(0.07)\end{array}$ \\
\hline $\begin{array}{l}\text { Electricity Exports } \\
\text { (net) }\end{array}$ & & $\begin{array}{l}-0.02 * * * \\
(0.00)\end{array}$ & $\begin{array}{l}-0.01 * * * \\
(0.00)\end{array}$ & $\begin{array}{l}-0.02^{* * *} \\
(0.00)\end{array}$ & $\begin{array}{l}-0.01^{* * *} \\
(0.00)\end{array}$ \\
\hline $\begin{array}{l}\text { GDP Per Capita } \\
\text { (logged) }\end{array}$ & & $\begin{array}{l}2.14 \\
(9.46)\end{array}$ & $\begin{array}{l}2.10^{*} \\
(1.18)\end{array}$ & $\begin{array}{l}2.14 \\
(9.63)\end{array}$ & $\begin{array}{l}2.00^{*} \\
(1.19)\end{array}$ \\
\hline Constant & $\begin{array}{c}1.74 \\
(1.41)\end{array}$ & $\begin{array}{c}-16.92 \\
(85.16)\end{array}$ & $\begin{array}{c}-16.67 \\
(10.40)\end{array}$ & $\begin{array}{r}-16.49 \\
(86.79)\end{array}$ & $\begin{array}{r}-15.30 \\
(10.52)\end{array}$ \\
\hline Province FE & YES & YES & NO & YES & NO \\
\hline Year FE & YES & YES & YES & YES & YES \\
\hline Observations & 703 & 694 & 694 & 694 & 694 \\
\hline$R$-squared & 0.04 & 0.06 & 0.06 & 0.07 & 0.07 \\
\hline \# of provinces & 31 & 31 & 31 & 31 & 31 \\
\hline
\end{tabular}

Note: dependent variable is Provincial GDP Growth-Electricity Production Growth, quarterly data from 2001-08. Robust standard errors in parentheses. ${ }^{* *} \mathrm{p}<0.01,{ }^{* *} \mathrm{p}<0.05,{ }^{*} \mathrm{p}<0.1$.

1.5 per cent boost could turn a middling 10 per cent growth rate for a province into a top performer at 11.5 per cent. Industrial growth has the same strongly negative estimated effect that it does in the annual analysis. Yet the estimates for GDP Per Capita are muted in the quarterly analysis. The annual analysis saw higher GDP growth estimates in richer provinces. This difference could be due to some of the wealth effect being captured by the Electricity Exports variable, as the electricity-importing provinces are overwhelmingly wealthy. As expected, there is a very large and significant negative coefficient on these net exports of electricity: electricity exporters have faster electricity production growth than GDP growth compared with other provinces, while importers exhibit the reverse. Indeed, this is how a province becomes an exporter or importer of electricity.

Models 2.4 and 2.5, which use $\Delta$ Turnover, lend additional credence to the Juking the Stats Hypothesis. This variable picks up what appears to be inflation of GDP at the end of leader's tenure as well as deflation of GDP estimates immediately following turnovers. The mean growth rate differential between years with turnover and years after turnover is nearly 2.5 percentage points $(-0.48$ vs. -2.94$)$.

The results demonstrate a clear pattern of growth rate differentials aligning with political cycles. Of course, other explanations could account for what has been captured here. I argue that politicians facing cyclical pressures on performance metrics manipulate economic data in their regions at key moments. Yet it is plausible that a real political business cycle could account for some or all of the variance I attribute to data manipulation. A relative gain in GDP growth over electricity consumption growth, as happens in years with turnover, could be associated with an increase in real development that does not use electricity intensively. However, sectors linked with political business or budget cycles in China - services and construction - have little effect on the statistical significance of the Turnover variable. ${ }^{61}$ For instance, as noted above, significant gains in

61 See Appendix Table 4 for this and other results. 
the service sector would be reflected in the GDP series more than the electricity series. Loans or government expenditures geared toward immediate spending at the end of the political cycle would be reflected through growth in services or construction channels. ${ }^{62}$ Yet the turnover effect survives the inclusion of the service sector share of GDP, as shown in Model 1.4, and is resilient to the inclusion of construction growth as well. ${ }^{63}$ Neither result diminishes confidence in the support of juking the stats during the height of the political cycle.

A critique from the opposite point of view, which is skeptical not only of Chinese provincial-level GDP growth rates but the entire Chinese statistical apparatus, is faced with similar difficulties in explaining these patterns. If the numbers are all a fiction, it is unclear what purpose there would be in incrementally increasing the GDP growth rate beyond the electricity growth rate in turnover years other than to report success in that province. That is, if the numbers are all theater, then the audience seems to favor reporting high GDP growth numbers in years with political turnover.

\section{DISCUSSION}

This article investigates the possibility, which is perhaps widely assumed but rarely (if ever) documented, that GDP data are systematically manipulated for political ends. To be clear, I refer not to the manipulation of the economy for political ends - that is, the political business cycle in which politicians stimulate the economy near election time - but rather to the manipulation of official economic data. In dictatorships, where the quality of information about the state of the world is imperfect at best, such a maneuver may reap political rewards at relatively low cost. Rather than trying to stimulate the economy to engender political support from the masses, elites, foreign investors or others, dictators might attempt to deceive these audiences by adjusting a summary statistic that supposedly represents the state of the economy. At sub-national levels, the incentives to manipulate data may be even more pronounced. When the principals assessing a local official live outside his or her region, adjusting a growth estimate might be a relatively inexpensive way for local agents to change the perceptions of higher-ups about the situation on the ground. ${ }^{64}$

Using differences in the political sensitivity of data and over time, patterns that are consistent with data manipulation emerge. Dictatorships systematically differ from democracies in their relationships between electricity consumption and GDP. At the subnational level in China, provinces report higher GDP over electricity growth differentials in years with political turnover than in other years, even after controlling for potential real economic factors that might account for this pattern. What are the implications of these results? Theoretically, it improves our understanding of the limits of accountability mechanisms in dictatorships, and can shed light on the non-transparent world of politics inside such regimes. Empirically, it calls for a reassessment of the effects of economic growth on authoritarian regime collapse, as systematic dissembling could strengthen or

62 Blaydes 2010; Guo 2009.

${ }^{63}$ Unlike the service sector with its low electricity intensity, construction is a more complex activity that has more or less intense electricity use at different points in the economic chain. Perhaps for this reason, construction growth has little explanatory power, and its inclusion does not affect the ability of turnover to account for variation in the GDP growth estimate.

${ }^{64}$ The probability of being caught might be low enough to outweigh even serious punishment if fraud were to be exposed. 
weaken extant results. Finally, it suggests that caution is appropriate in the use of politically sensitive economic statistics, particularly from dictatorships.

Why do dictatorships use these data in evaluating promotions if they are manipulated, as I have suggested? Performance targets set for lower levels will be evaluated by monitors either under the control of the lower-level official being judged or from outside the territory. The former may possess the information but lack the will to report it. The latter possesses the will, but faces difficulties in acquiring independent information. A dictator's unappetizing alternatives are therefore unreliable information or the use of monitoring methods that come with their own costs. Private citizens use elections to hold officials accountable for poor performance, but opponents can also use elections to undermine a regime. ${ }^{65}$ Others have suggested that protests can operate as a fire alarm, alerting the center that their attention is required to redress local abuses. ${ }^{66}$ However, protests have their own risks, as the Arab Spring uprisings in Tunisia and Egypt have shown.

Performance evaluations using data that is subject to manipulation may also be part of a regime-strengthening ritual. The inflation of GDP figures could, of course, simply be fooling officials at the center who reward apparent star performers based on reported figures. However, that high-level party officials seem to be aware of this kabuki theater discourages a purely naïve interpretation. The local official might instead be signaling to the center that she understands the political game of the party-state or her ability to accomplish goals despite bureaucratic obstacles. Alternatively, bureaucrats might juke the stats as a signal of respect to an outgoing leader or, more intriguingly, as a positive signal about the locality. A province with fast growth might attract a stronger leader or dissuade the center from dispatching a reforming crusader to change the status quo. I leave distinguishing these mechanisms to future research.

A cross-national implication of this work is that regimes are more likely to manipulate economic data during times of crisis. First, the rewards are greater. That is, we have a robust finding in the democratization and authoritarian regime survival literature that regimes tend to be ousted during periods of economic turmoil (for example, Geddes 1999; Wallace 2013). As such, manipulating economic data might hide the extent of an economic downturn until government policy can ameliorate the situation, allowing the regime to survive a particularly vulnerable moment. Secondly, the costs are minimized. While data manipulation may be expensive in the long run, loss of credibility is damaging for a leader or regime only if it believes that it will be the one that has to pay those costs. However, if a regime believes that its very grasp on power is no longer certain, then it might be willing to engage in extraordinary behavior.

With the extant finding that regimes collapse during time of economic crisis, ${ }^{67}$ one possible implication of this work is that the previous finding underestimates the true effect of crisis on survival, as regimes are most likely to be padding the data during such periods. That is, if the crises that coincide with the end of regimes are more severe than the official record led us to believe, then we will find an even stronger correlation between crisis and collapse with the real values. The official statistics might be masking other variation that could further strengthen or undermine the finding that economic crisis leads to regime collapse. If regimes suffer from economic crises more often than is reported in the official economic data series, and if these previously hidden economic crises are associated with

65 Beissinger 2007; Diaz-Cayeros, Magaloni, and Weingast 2003; Magaloni 2006.

66 Lorentzen 2013.

67 Acemoglu and Robinson 2005; Chiozza and Goemans 2004; Geddes 1999. 
regime collapses, the extant result is again strengthened. Yet if there are cases in which the political manipulation of economic data hides economic crises that are not associated with regime collapses, then the political manipulation could have been said to work. A large number of economic crises hidden in the official records could undermine the finding that economic crises are linked to regime collapses. Further work is required to answer these fascinating and constructive questions.

These results offer a critical assessment of the messy world of Chinese and crossnational economic data, which are ubiquitous in the political world and the quantitative study of political economy. These statistics drive our assessments of policy and policy makers, of countries on the rise and wane, and of the present and future. Politically sensitive data such as GDP at the national and sub-national levels are likely targets of manipulation. When possible, researchers should use a close correlate that is less likely to be manipulated, such as electricity consumption or production, as a robustness check to ensure that their findings are not driven by artifacts of political games rather than economic realities. Macroeconomic statistics are complicated constructs and serve as political statements. They should be treated with as much caution as the words of the politicians who announce them, since ultimately the collectors of the data report to the politicians who run the bureaucracy and the country.

\section{REFERENCES}

Acemoglu, D., and J.A. Robinson. 2005. Economic Origins of Dictatorship and Democracy. Cambridge: Cambridge University Press.

Ames, B. 1970. Bases of Support for Mexico's Dominant Party. The American Political Science Review 64 (1):153-67.

Andrews, Steven. 2011. Beijing's Hazardous Blue Sky. chinadialogue.net. 12 May.

Areddy, J. 2013. China Absent from Corruption Report. Wall Street Journal 10 July.

Bachman, D.M. 1991. Bureaucracy, Economy, and Leadership in China: The Institutional Origins of the Great Leap Forward. Cambridge: Cambridge University Press.

Beissinger, M.R. 2007. Structure and Example in Modular Political Phenomena: The Diffusion of Bulldozer/Rose/Orange/Tulip Revolutions. Perspectives on Politics 5 (2):259-76.

Blaydes, L. 2010. Elections and Distributive Politics in Mubarak's Egypt. Cambridge: Cambridge University Press.

Bueno de Mesquita, B., A. Smith, R.M. Siverson, and J.D. Morrow. 2003. The Logic of Political Survival. Cambridge: MIT Press.

Canaves, S. 2009. Song of Statistics: Odes to the Motherland from an Unlikely Source. Wall Street Journal. 31 July.

Cheibub, J.A., J. Gandhi, and J.R. Vreeland. 2010. Democracy and Dictatorship Revisited. Public Choice 143 (1):67-101.

Chiozza, G., and H.E. Goemans. 2004. International Conflict and the Tenure of Leaders: Is War Still Ex Post Inefficient? American Journal of Political Science 48 (3):604-19.

Demick, B. 2011. U.S. Embassy Air Quality Data Undercut China's Own Assessments. Los Angeles Times. 29 October.

Diaz-Cayeros, A., B. Magaloni, and B. Weingast, 2003. Tragic Brilliance: Equilibrium Party Hegemony in Mexico. SSRN Working Paper.

Drazen, A. 2001. The Political Business Cycle After 25 Years. Cambridge, MA: MIT Press.

Fearon, J.D. 2011. Self-Enforcing Democracy. Quarterly Journal of Economics 126 (4):1661-708.

Gandhi, J. 2008. Political Institutions under Dictatorship. Cambridge: Cambridge University Press.

Geddes, B. 1999. What do We Know about Democratization after Twenty Years. Annual Review of Political Science 2:115-44. 
Geddes, B., and J. Zaller. 1989. Sources of Popular Support for Authoritarian Regimes. American Journal of Political Science 33 (2):319-47.

Gleditsch, K.S. 2002. Expanded Trade and GDP Data. The Journal of Conflict Resolution $46(5): 712-24$.

Guo, G. 2007. Retrospective Economic Accountability under Authoritarianism. Political Research Quarterly 60 (3):378-90.

- 2009. China's Local Political Budget Cycles. American Journal of Political Science 53 (3):621-32.

Heston, A. 1994. A Brief Review of Some Problems in Using National Accounts Data in Level of Output Comparisons and Growth Studies. Journal of Development Economics 44 (1):29-52.

Hollyer, J.R., B.P. Rosendorff, and J.R. Vreeland. 2011. Democracy and Transparency. The Journal of Politics 73 (4):1191-205.

Holz, C.A. 2005. OECD-China Governance Project: The Institutional Arrangements for the Production of Statistics. Statistics Working Papers, OECD.

— 2008. China's 2004 Economic Census and 2006 Benchmark Revision of GDP Statistics: More Questions Than Answers? The China Quarterly 193:150-63.

Huntington, S.P. 1968. Political Order in Changing Societies. New Haven, CT: Yale University Press.

Johnson, S., D. Kaufmann, and A. Shleifer 1997. The Unofficial Economy in Transition. Brookings Papers on Economic Activity 1997 (2): 159-239.

Kayser, M.A. 2005. Who Surfs, Who Manipulates? The Determinants of Opportunistic Election Timing and Electorally Motivated Economic Intervention. American Political Science Review 99 (1):17-27.

Kerner, A., M. Jerven, and A. Beatty. 2013. Real Money, Fake Data: The Political Economy of World Bank Data Manipulation. IPES Working Paper.

Kung, J.K-S., and S. Chen. 2011. The Tragedy of the Nomenklatura: Career Incentives and Political Radicalism During China's Great Leap Famine. American Political Science Review 105 (1):27-45.

Kuran, T. 1991a. Now Out of Never: The Element of Surprise in the East European Revolution of 1989. World Politics 44 (1):7-48.

—. 1991b. The East European Revolution of 1989: Is it Surprising that We Were Surprised? American Economic Review 81 (2):121-5.

Landry, P.F. 2008. Decentralized Authoritarianism in China: The Communist Party's Control of Local Elites in the Post-Mao Era. Cambridge: Cambridge University Press.

Li, C. 2010. China's Midterm Jockeying: Gearing Up for 2012 Part 1: Provincial Chiefs. China Leadership Monitor (31):1-24.

Lin, J.Y., and D.T. Yang. 2000. Food Availability, Entitlements and the Chinese Famine of 195961. Economic Journal 110 (460):136-58.

Lorentzen, P.L. 2013. Regularizing Rioting: Permitting Public Protest in an Authoritarian Regime. Quarterly Journal of Political Science 8 (2):127-58.

Lupia, A, and M.D. McCubbins. 1998. The Democratic Dilemma: Can Citizens Learn What They Need to Know? Cambridge: Cambridge University Press.

Lü, X., and P.F. Landry. (forthcoming). Show Me the Money: Inter-Jurisdiction Political Competition and Fiscal Extraction in China. American Political Science Review.

Magaloni, B. 2006. Voting for Autocracy: Hegemonic Party Survival and Its Demise in Mexico. New York: Cambridge University Press.

Naughton, B. 2007. The Chinese Economy. Cambridge, MA: MIT Press.

Nordhaus, W.D. 1975. The Political Business Cycle. The Review of Economic Studies 42 (2):169-90.

Ober, J. 2008. Democracy and Knowledge: Innovation and Learning in Classical Athens. Princeton, NJ: Princeton University Press.

Pepinsky, T. 2007. Autocracy, Elections, and Fiscal Policy: Evidence from Malaysia. Studies in Comparative International Development 42 (1):136-63. 
Rawski, T.G. 2001. What is Happening to China's GDP Statistics? China Economic Review $12(4): 347-54$.

Schmitter, P., and T. Karl. 1991. What Democracy Is \& Is Not. Journal of Democracy 2:75-88.

Shih, V., C. Adolph, and M. Liu. 2012. Getting Ahead in the Communist Party: Explaining the Advancement of Central Committee Members in China. American Political Science Review $106(1): 166-87$.

Shleifer, A., and R.W. Vishny. 1999. The Grabbing Hand: Government Pathologies and Their Cures. Cambridge, MA: Harvard University Press.

Simpser, A. 2013. Why Governments and Parties Manipulate Elections: Theory, Practice, and Implications. Cambridge: Cambridge University Press.

Sinton, J.E. 2001. Accuracy and Reliability of China's Energy Statistics. China Economic Review $12(4): 373-83$.

Smith, A. 2004. Election Timing. Cambridge: Cambridge University Press.

Smith, Yves. 2009. China Claims 6.8\% Economic Growth for 4Q 2008. Naked Capitalism 22 January.

Tao, Y.F. 2006. The Evolution of 'Political Business Cycle' in Post-Mao China. Issues \& Studies 42 (1):163-94.

Teorell, J., M. Samanni, S. Holmberg, and B. Rothstein 2011. Quality of Government Dataset, version. Quality of Government Institute. Available from http://www.qog.pol.gu.se, accessed 6 April 2011.

Tsai, L.L. 2008. Understanding the Falsification of Village Income Statistics. The China Quarterly 196:805-26.

Wallace, J. 2013. Cities, Redistribution, and Authoritarian Regime Survival. Journal of Politics 75 (3):632-45.

Whiting, S.H. 2000. Power and Wealth in Rural China: The Political Economy of Institutional Change. Cambridge: Cambridge University Press.

Wright, J. 2008. Do Authoritarian Institutions Constrain? How Legislatures Affect Economic Growth and Investment. American Journal of Political Science 52 (2):322-43. 